\title{
MEDIA AUDIO VISUAL : PENGARUHNYA TERHADAP PERKEMBANGAN MORAL ANAK USIA DINI
}

\author{
Oleh : \\ Rabitah Hanum Hasibuan', Veryawan², Ade Tursina ${ }^{3}$ \\ ${ }^{1}$ STAI Syekh H. Abdul Halim Hasan Al-Islahiyah Binjai \\ ${ }^{2,3}$ Institut Agama Islam Negeri Langsa \\ Email: rabithahanum091284@gmail.com, veryawan@iainlangsa.ac.id, \\ adetursina@iainlangsa.ac.id
}

Diterima 8 Maret 2021, direvisi 28 September 2021, diterbitkan 1 Oktober 2021

\begin{abstract}
Abstrak
Perkembangan moral anak sangat dipengaruhi oleh lingkungan sekitar maka dari itu tidak dapat dianggap remeh, karena moral merupakan suatu hal yang sangat penting dan sangat berpengaruh dalam kehidupan sosial masyarakat seseorang. Salah satu pilihan media pembelajaran dalam mengembangkan perkembangan moral anak adalah dengan menggunakan media audio visual. Audio visual itu adalah media yang dapat dilihat dan didengarkan audio visual yang diperlihatkan kepada anak-anak ini hanya terbatas pada video. Alasan penggunaan media audio visual adalah karena kemampuan dalam melukiskan gambaran hidup dan suara yang memberikan daya tarik tersendiri. Tujuan dilakukannya penelitian ini adalah untuk mengetahui perkembangan moral anak, pelaksanaan media audio visual dan mengetahui pengaruh media audio visual terhadap moral anak di $\mathrm{RA} \mathrm{Hj}$. Fauziah Kecamatan Binjai Timur Kota Binjai. Penelitian yang dilakukan ini bersifat kuantitatif. Dalam penelitian kuantitatif pada umumnya data yang diperoleh berbentuk angka-angka atau skor-skor yang dipadukan setelah mengambil nilai skor melalui angket yang disebarkan kepada sampel penelitian. Untuk selanjutnya, angkaangka itu diuji dengan angka-angka yang menjadi variabel kedua sehingga akan terjadi sebuah angka atau skor akhir yang dapat menentukan apakah di antara dua variabel itu ada hubungan saling mempengaruhi atau tidak. Jenis statistik yang dipakai adalah statistik Kolerasi Product Momen Person yaitu untuk mengetahui pengaruh media audio visual terhadap moral anak pada kelompok B di RA Hj. Fauziah Kecamatan Binjai Timur Kota Binjai. Adapun populasi dalam penelitian ini adalah siswa RA Hj. Fauziah Kecamatan Binjai Timur Kota Binjai pada tahun pelajaran 2020/2021 yang berjumlah 63 orang yang terdiri dari 38 orang siswa laki-laki dan 25 orang siswa perempuan. Hasil penelitian dengan media audio visual dapat dikatakan baik. Hal ini dapat dibuktikan dengan nilai yang diperoleh yaitu $\mathrm{P}=72,93 \%$. Penelitian untuk moral anak dapat dikatakan sangat baik. Hal ini dapat dibuktikan dengan nilai yang diperoleh yaitu $\mathrm{P}$ $=80,38 \%$. Terdapat pengaruh yang signifikan antara media audio visual moral anak yang dibuktikan dengan nilai koefisien korelasi (r) yang menunjukkan tingkat korelasi antara variabel $\mathrm{X}$ (media audio visual) dan variabel Y (moral anak pada kelompok B) sebesar $\mathrm{r}=0,68$ dengan tingkat korelasi tinggi. Berdasarkan uji statistik t yaitu $\mathrm{t}$ hitung $=\mathrm{r} \sqrt{\mathrm{n}-1}$ didapatkan hasil 3,18. Jadi, dapat disimpulkan bahwa terdapat pengaruh yang signifikan antara media audio visual terhadap moral anak pada kelompok B di RA Hj. Fauziah Binjai.
\end{abstract}

Kata Kunci : Audio Visual, Perkembangan Moral, Anak Usia Dini 


\begin{abstract}
The moral development of children is strongly influenced by the surrounding environment and therefore cannot be underestimated, because morals are something that is very important and very influential in one's social life. One of the choices of learning media in developing children's moral development is to use audio-visual media. Audio visuals are media that can be seen and listened to. Audio visuals shown to children are only limited to videos. The reason for using audio-visual media is because of the ability to paint live pictures and sound that gives it its own charm. The purpose of this study was to determine the moral development of children, the implementation of audio-visual media and to determine the effect of audio-visual media on the morals of children in RA Hj. Fauziah, East Binjai District, Binjai City. This research is quantitative in nature. In quantitative research, in general, the data obtained are in the form of numbers or scores that are combined after taking the scores through a questionnaire distributed to the research sample. Henceforth, these numbers are tested with numbers that become the second variable so that a final number or score will occur that can determine whether between the two variables there is a mutually influencing relationship or not. The type of statistic used is the Product Moment Person Correlation statistic, which is to determine the effect of audio-visual media on the morale of children in group B in RA Hj. Fauziah, East Binjai District, Binjai City. The population in this study were students $R A H j$. Fauziah, East Binjai District, Binjai City in the 2020/2021 academic year, totaling 63 people consisting of 38 male students and 25 female students. The results of research with audio-visual media can be said to be good. This can be proven by the value obtained, namely $P=72.93 \%$. Research for children's morals can be said to be very good. This can be proven by the value obtained, namely $P=80.38 \%$. There is $a$ significant effect between audio-visual media on children's morals as evidenced by the correlation coefficient $(r)$ which shows the level of correlation between the $X$ variable (audiovisual media) and $Y$ (child morale in group B) of $r=0.68$ with a correlation level tall. Based on the $t$ statistical test, namely $t$ count $=r \sqrt{ }(n-1)$, the result is 3.18. So, it can be concluded that there is a significant influence between audio-visual media on children's morals in group $B$ in RA Hj. Fauziah Binjai.
\end{abstract}

Keywords: Audio Visual, Moral Development, Early Childhood

\section{PENDAhuluan}

Menurut Rahim Rahiem, 2014 dalam (Khaironi 2017) menjelaskan "Early childhood is a crucial stage in terms of a child's physical, intellectual, emotional and social development. Mental and physical abilities progress at an astounding rate and a very high proportion of learning takes place from birth to age six years old." Usia dini adalah usia kritis pada perkembangan fisik, intelektual, dan sosial emosional. Ratarata kemajuan kemampuan fisik dan rohani sangat pesat pada usia baru lahir hingga enam tahun. Kemajuan perkembangan tersebut diperoleh melalui hasil belajar dari lingkungan. Mengingat pentingnya keberadaan usia dini, maka diperlukan adanya pemberian stimulasi yang optimal pada usia tersebut, sehingga pertumbuhan dan perkembangan anak dapat berjalan sebagaimana mestinya . Anak usia dini merupakan individu yang sedang mengalami proses pertumbuhan dan perkembangan yang sangat pesat, bahkan dikatakan sebagai lompatan perkembangan. Dimana pada masa ini sering disebut masa keemasan (golden age) yang dimana anak dapat menyerap segala sesuatu yang cepat. Perkembangan anak usia dini dapat dilihat dari beberapa aspek, seperti kognitif, bahasa, fisik 
motorik, nilai agama dan moral, sosial emosional serta seni. Anak yang mendapatkan pembinaan sejak dini akan dapat meningkatkan kesehatan dan kesejahteraan fisik dan mental, yang akan berdampak pada peningkatan prestasi belajar, etos kerja dan produktivitas (Veryawan, Juliati, and Aprilia 2020).

Perkembangan moral anak sangat dipengaruhi oleh lingkungan sekitar maka dari itu tidak dapat dianggap remeh, karena moral merupakan suatu hal yang sangat penting dan sangat berpengaruh dalam kehidupan sosial masyarakat seseorang. Menurut Hidayat (Aisyah 2012) bahwa moral mengacu pada aturan-aturan umum mengenai benar-salah atau baik-buruk yang berlaku dimasyarakat luas. Menurut Ouska dan Whellan (Ananda 2017), moral adalah prinsip baik-buruk yang ada dan melekat dalam diri individu atau seseorang. Walaupun moral itu berada dalam diri individu, tetapi moral berada dalam suatu sistem yang berwujud aturan. Moral dan moralitas memiliki sedikit perbedaan, karena moral adalah prinsip baik-buruk sedangkan moralitas merupakan kualitas pertimbangan baik-buruk. Dengan demikian, hakekat dan makna moralitas bisa dilihat dari cara individu yang memiliki moral dalam mematuhi maupun menjalankan aturan.

Wuryandani (Siwiyanti 2016) menerangkan bahwa dalam perkembangannya moral diartikan sebagai kebiasaan dalam bertingkah laku yang baik, yang susila. Dari pengertian tersebut dinyatakan bahwa moral adalah berkenaan dengan kesusilaan. Seorang individu dapat dikatakan baik secara moral apabila bertingkah laku sesuai dengan kaidah-kaidah moral yang ada. Sebaliknya jika perilaku individu itu tidak sesuai dengan kaidahkaidah yang ada, maka ia akan dikatakan jelek secara moral. Sedangkan (Maharani 2014) mengungkapkan bahwa sikap adalah perilaku yang berisi pendapat tentang sesuatu. Dalam sikap positif tersirat sistem nilai yang dipercayai atau diyakini kebenarannya. Nilai adalah suatu yang diyakini, dipercaya, dan dirasakan serta diwujudkan dalam sikap atau perilak. Biasanya, nilai bermuatan pegalaman emosional masa lalu yang mewarnai citacita seseorang, kelompok atau masyarakat. Moral merupakan wujud abstrak dari nilainilai, dan tampilan secara nyata atau kongkret dalam perilaku terbuka yang dapat diamati. Sikap moral muncul dalam praktek moral dengan kategori positif atau menerima, netral, atau negative atau menolak. Beberapa nilai yang selama ini harus dikenalkan dan ditanamkan kepada anak antara lain: kedamaian, penghargaan, cinta, tanggung jawab, kebahagiaan, kerjasama/gotong royong, kejujuran, kerendahan hati, kesederhanaan, saling berbagi, keberanian, dan tolong menolong (Qadafi 2019).

Anak-anak senantiasa tumbuh dan berkembang. Mereka menampilkan ciri-ciri fisik dan psikologi yang berbeda untuk tiap tahap perkembangannya. Masa anak-anak merupakan masa puncak kreativitasnya dan kreativitas mereka perlu dijaga dan dikembangkan dengan menciptakan lingkungan yang menghargai kreativitas yaitu melalui bermain. Oleh karena itu, pendidikan di PAUD yang menekankan bermain sambil belajar dapat mendorong anak untuk mengeluarkan semua daya kreativitasnya. Penggunaan media pembelajaran dapat memperjelaskan pesan yang ingin disampaikan kepada anak, dapat membantu anak untuk meningkatkan perkembangan moralnya, serta membuat pembelajaran lebih bervariasi dan diharapkan agar pembelajaran yang dilakukan anak lebih bermakna.

Penerapan media pembelajaran ini manfaatnya banyak antara lain sebagai berikut 1) Anak dapat melihat dan 
mendengar langsung pembelajaran 2) Media pembelajaran dapat diterapkan dan diakses langsung melalui internet 3) Media ini dapat mengatasi jarak dan waktu 4) Mampu menggambarkan peristiwa-peristiwa masa lalu secara realistis dalam waktu yang singkat 5) Dapat diulang-ulang bila perlu dan volume suara dapat diubah dari kecil, sedang dan besar 6) Pesan yang disampaikannya cepat dan mudah di ingat 7) Dapat mengembangkan pikiran dan pendapat peserta didik 8) Dapat mengembangkan imajinasi peserta didik 9) Dapat menarik dan meningkatkan minat/daya tarik serta perhatian peserta didik 10) Memperjelas hal-hal yang abstrak dan memberikan penjelasan yang lebih realistis 11) Peserta didik dapat mengenal dan mengetahui bilangan atau angka, huruf, ukuran, gambar, bentuk, warna dsb (Jalil and Hawang 2018).

Salah satu pilihan media pembelajaran dalam mengembangkan perkembangan moral anak adalah dengan menggunakan media audio visual. Audio visual itu adalah media yang dapat dilihat dan didengarkan audio visual yang diperlihatkan kepada anak-anak ini hanya terbatas pada video. Alasan penggunaan media audio visual adalah karena kemampuan dalam melukiskan gambaran hidup dan suara yang memberikan daya tarik tersendiri. Menurut (Fithri and Pradipta 2017) menerangkan bahwa media audio visual adalah media intruksional modern yang sesuaidengan perkembangan zaman yaitu kemajuan ilmu pengetahuan dan teknologi. Sesuai dengan namanya media ini merupakan kombinasi dari audio (melalui pendengaran) dan visual (melalui penglihatan).

Arsyad, 2010 (Oktaviani and Kamtini 2017) mendefinisikan bahwa media audiovisual adalah jenis media yang digunakan dalam kegiatan pembelajaran dengan melibatkan pendengaran dan pengelihatan sekaligus dalam satu proses atau kegiatan. Pesan dan informasi yang dapat disalurkan melalui media ini dapat berupa pesan verbal dan non verbal yang mengandalkan baik pengelihatan dan pendengaran. Beberapa contoh media audiovisual adalah laptop atau komputer, proyektor dan televisi. Manfaat media audio visual menurut Andre Rinanto (dalam Purwasih, 2014) yaitu, (a) media audio visual dapat mengatasi keterbatasan pengalaman yang dimiliki anak didik, (b) media audio visual dapat melampaui batasan ruang dan waktu, (c) media audio visual sangat memungkinkan terjadinya interaksi langsung antara anak didik dengan lingkungannya, (d) media audio visual memberikan keragaman pengamatan, (e) media audio visual dapat menanamkan konsep dasar yang besar, konkrit, dan realistis, (f) media audio visual membangkitkan keinginan dan minat baru, (g) media audio visual memberikan pengalaman yang integral dari yang konkrit ke abstrak (Ernayanti, Pudjawan, and Mahadewi 2017). Sejalan tujuan dan fungsinya, media audio visual memiliki kelebihan dan kekurangan. Kelebihannya meliputi (a) dapat digunakan untuk klasikal, (b) dapat digunakan seketika, (c) digunakan secara berulang, (d) dapat menyajikan materi secara fisik tidak dapat bicara ke dalam kelas, (e) dapat menyajikan objek yang bersifat bahaya, (f) dapat menyajikan objek secara detail, (g) tidak memerlukan ruang gelap, (h) dapat di perlambat dan dipercepat, (i) menyajikan gambar dan suara. Adapun kelemahan media audio video adalah (a) sukar untuk dapat direvisi, (b) relatif mahal, (c) memerlukan keahlian khusus, (d) peralatan harus lengkap (Fitria 2014).

Namun pada kenyataannya berdasarkan observasi yang dilakukan peneliti dari 23 anak dapat dipresentasikan bahwa yang memiliki moral yang baik ada 8 anak didik atau $30 \%$ dan anak yang tidak memiliki 
moral yang tidak baik ada 15 anak didik atau 70\%. Hal ini dikarenakan adanya masalah yang menjadi acuan dalam penelitian yaitu: Pertama, kurangnya pengetahuan anak mengenai perbuatannya yang benar/salah yaitu terlihat ketika bermain terdapat anak yang menendang temannya hingga menangis sebanyak $25 \%$. Kedua, masih ada anak yang merampas makanan temannya sebanyak $20 \%$. Ketiga, tidak mau saling memaafkan jika melakukan kesalahan sebanyak 35\%. Keempat, anak tidak dapat menyelesaikan pekerjaan yang diberikan oleh gurunya sebanyak $10 \%$. Kelima, kurang sopannya anak menarik jilbab gurunya saat jam pelajaran sebanyak 5\%. Keenam, kurangnya kedisiplinan anak sehingga pada saat jam pelajaran anak keluar kelas 5\%. Sehingga pada penelitian ini, peneliti akan memilih media audio visual untuk perkembanngan moral anak menjadi lebih baik lagi. Dengan durasi yang tidak membosankan. Dan tentu saja terdapat nilai-nilai kehidupan di dalamnya.

Penelitian sebelumnya yang pernah dilakukan oleh (Suparya 2020) menunjukkan bahwa terdapat pengaruh yang signifikan metode bercerita berbantuan media audio visual dengan setting lesson study terhadap perkembangan bahasa anak kelompok B TK Widya Kumara Sidhi dengan nilai gains skor ternormalisasi sebesar 0,612 atau berada pada kategori sedang. Dan juga (Primayana, Dewi, and Gunawan 2020) bahwa perilaku belajar anak kelompok B TK Dharma Suda Singaraja dan kelompok B TK Aisyiyah Bustanul Athfal bahwa nilai rata-rata anak kelompok B TK Dharma Suda Singaraja mengaplikasikan model pembelajaran Project Based Outdoor Learning Activity menggunakan media Audio Visual adalah 64,28, lebih tinggi dibandingkan nilai rerata anak kelompok $\mathrm{B}$ TK Aisyiyah Bustanul Athfal dengan menggunakan pembelajaran konvensional adalah 50,33, sehingga dapat disimpulkan pembelajaran Project Based Outdoor Learning Activity menggunakan media Audio Visual lebih baik dari pada menggunakan pembelajaran konvensional.

Berdasarkan fenomena di atas maka peneliti merasa tertarik melakukan penelitian yang berjudul "Pengaruh Media Audio Visual Terhadap Moral Anak Pada Kelompok B Di RA Fauziah Kecamatan Binjai Timur Kota Binjai”.

\section{METODE}

Penelitian ini dilaksanakan di $\mathrm{RA} \mathrm{Hj}$. Fauziah Jalan Danau Sentani No. 1 Kelurahan Tunggurono Kecamatan Binjai Timur Kota Binjai Sumatera Utara. Adapun waktu penelitian ini dilakukan pada bulan Juli - November 2020. Penelitian yang dilakukan ini bersifat kuantitatif. Dalam penelitian kuantitatif pada umumnya data yang diperoleh berbentuk angka-angka atau skor-skor yang dipadukan setelah mengambil nilai skor melalui angket yang disebarkan kepada sampel penelitian. Untuk selanjutnya, angka-angka itu diuji dengan angka-angka yang menjadi variabel kedua sehingga akan terjadi sebuah angka atau skor akhir yang dapat menentukan apakah di antara dua variabel itu ada hubungan saling mempengaruhi atau tidak. Jenis statistik yang dipakai adalah statistik Kolerasi Product Momen Person yaitu untuk mengetahui pengaruh media audio visual terhadap moral anak pada kelompok B di RA Hj. Fauziah Kecamatan Binjai Timur Kota Binjai. Populasi adalah sekelompok elemen atau kasus, baik itu individual, objek, atau peristiwa, yang berhubungan dengan kriteria spesifik dan merupakan sesuatu menjadi target generalisasi yang ditetapkan peneliti untuk dipelajari dan ditarik kesimpulannya. Adapun populasi dalam penelitian ini adalah siswa $\mathrm{RA} \mathrm{Hj}$. Fauziah Kecamatan Binjai Timur Kota Binjai pada tahun pelajaran 2020/2021 yang berjumlah 63 orang yang terdiri dari 38 
orang siswa laki-laki dan 25 orang siswa perempuan.

Menurut Arikunto (Djamarah and Zain 2010) sampel adalah sebagian atau wakil populasi yang diteliti, sampel adalah bagian dari jumlah populasi yang diteliti sehingga hasil penelitian bisa digeneralisasikan, generalisasi hasil penelitian oleh sampel berlaku juga bagi populasi penelitian tersebut. Dalam suatu penelitian, pada umumnya observasi dilakukan tidak bertahap populasi, akan tetapi dilaksanakan pada sampel. Sedangkan untuk menentukan beberapa jumlah sampel yang dipersyaratkan untuk suatu penelitian dari populasi yang tersedia. Juga tidak ada batasan yang jelas apa yang dimaksud dengan sampel besar dan yang kecil. Namun kebanyakan peneliti beranggapan bahwa semakin banyak sampel atau semakin banyak sampel dari populasi, maka hasil penelitiannya akan semakin baik.

Untuk mengukur kedua variabel penelitian digunakan kuesioner (angket) yang disusun menurut skala Likert. Alternatif jawaban untuk butir pernyataan yang menjaring aspek frekuensi tindakan atau perilaku dinyatakan dalam bentuk kontinum yang terdiri dari 4 skala, yaitu: Sangat sering, Sering, Kadang-kadang, dan Tidak Pernah. Sesuai dengan sifat kuesioner maka bobot pernyataan positif diberi skor 4,3,2,1 dan untuk negatif diberi skor 1,2,3,4. Dalam penyusunan instrumen diperhatikan beberapa hal yang berkenaan dengan: a) menghindari pertanyaan yang meragukan, b) menghindari kata-kata yang terlalu abstrak, c) tidak menggunakan kata-kata yang dapat menimbulkan rasa curiga dan antipati, d) penggunaan bahasa yang baik sehingga mudah diisi oleh responden. Untuk memperoleh data dari sumbernya dipergunakan beberapa alat pengumpulan data, yaitu: observasi, interview atau wawancara, angket dan dokumentasi. Data penelitian ini, data kualitatif dan diolah dalam bentuk uraian-uraian teoritis yang didukung dengan beberapa referensi. Sedangkan data kuantitatif disajikan dalam bentuk angka-angka dan dipindahkan dalam bentuk tabulasi data dengan mencantumkan frekuensi dan persentase.

Untuk mencari pengaruh antara variabel $\mathrm{X}$ (media audio visual) dan variabel $\mathrm{Y}$ (moral anak pada kelompok B), maka digunakan rumus Kolerasi Product Moment yaitu sebagai berikut:

$$
r x y=\frac{n \sum X Y-\left(\sum X\right)\left(\sum Y\right)}{\sqrt{\left\{\left(n X \sum X^{2}\right)-\left(\sum X^{2}\right)\right\}\left\{\left(n X \sum Y^{2}\right)-\left(\sum Y^{2}\right)\right\}}}
$$

Keterangan:

$\mathrm{r}_{\mathrm{xy}}=$ Koefisien skor $\mathrm{x}$ dan $\mathrm{y}$

$\Sigma \mathrm{X} \quad=$ Jumlah skor dalam variabel

$\mathrm{X}$

$\Sigma \mathrm{Y}=$ Jumlah skor dalam variabel

Y

$\Sigma \mathrm{XY}=$ Jumlah hasil skor $\mathrm{x}$ dengan skor y yang berpasangan

$\Sigma \mathrm{X}^{2}=$ Jumlah skor yang dikuadratkan dalam variabel $\mathrm{X}$

$\Sigma \mathrm{Y}^{2}=$ Jumlah skor yang dikuadratkan dalam variabel $\mathrm{Y}$

$\mathrm{N}=$ Banyak subyek skor $\mathrm{x}$ dan skor y yang berpasangan

Sedangkan untuk menafsirkan koefisien yang diperoleh dari perhitungan variabel $\mathrm{X}$ (Media Audio Visual) dan variabel Y (Moral Anak), peneliti memberikan nilai-nilai patokan sebagaimana yang telah ditetapkan oleh (Arikunto 2015) sebagai berikut:

$\begin{array}{lll}0,00-0,20 & = & \text { Kolerasi } \\ \text { yang sangat rendah } & = & \text { Kolerasi } \\ 0,20-0,40 & = & \text { Kolerasi } \\ \text { yang rendah } & = & \text { Kolerasi } \\ 0,40-0,60 & = & \text { Kolerasi } \\ \text { yang sedang } & & \\ 0,60-0,80 & & \\ \text { yang tinggi } & & \\ 0,80-1,00 & & \\ \text { yang sangat tinggi } & \text { Setelah diperoleh hasil uji signifikasi, } \\ \text { maka hasil tersebut dikonsultasikan kepada }\end{array}$


F tabel pada saraf signifikasi $5 \%$ dan $1 \%$ untuk melihat apakah pengaruh yang ditentukan signifikan atau tidak. Apabila F hitung $>\mathrm{F}$ tabel maka hipotesis diterima. Sebaliknya apabila $\mathrm{F}$ hitung $<\mathrm{F}$ tabel maka hipotesis ditolak.

\section{PEMBAHASAN}

Pembahasan ini bertitik tolak dari pernyataan apakah terdapat pengaruh media audio visual terhadap moral anak pada kelompok B di RA $\mathrm{Hj}$. Fauziah Binjai. Dalam penelitian ini diperoleh bahwa nilai koefisien korelasi (r) yang menunjukkan tingkat korelasi antara variabel $\mathrm{X}$ (media audio visual) dan variabel $\mathrm{Y}$ (moral anak pada kelompok B) sebesar $\mathrm{r}=0,68$ bahwa media ausio visual memiliki pengaruh dengan moral anak pada kelompok B.

Besarnya nilai (r) mengindikasikan bahwa pengaruh media audio visual terhadap moral anak pada kelompok B di RA Hj. Fauziah Binjai adalah tinggi. Dan angka indeks korelasi ini bertanda positif yang berarti bahwa pengaruh media audio visual terhadap moral anak pada kelompok B tersebut memilki korelasi positif (korelasi searah), yang mengindikasikan bahwa semakin tinggi nilai pengaruh media audio visual maka moral anak belajar pada kelompok B yang dicapai akan semakin baik.

Berdasarkan hasil penelitian diperoleh data skor tertinggi media audio visual yaitu 63, sedangkan skor terendah yaitu 53 dari data tersebut diketahui bahwa rentang jauh dan media audil visual terhadap moral anak pada kelompok B juga berbeda-beda. Sehingga dalam data ini diperoleh bahwa media audio visual di RA Hj. Fauziah Binjai berbeda-beda karena kecenderungan reaksi seorang siswa terhadap media audio visual juga tidak sama dengan siswa lainnya.

Untuk moral anak pada kelompok B diperoleh data skor tertinggi 69, sedangkan skor terendah 60 dari data tersebut diketahui bahwa rentang nilai moral anak pada kelompok B sangat tinggi. Keadaan ini memberikan gambaran bahwa siswa yang dijadikan sampel memiliki moral anak yang cukup tinggi dalam proses pembelajaran.

Sedangkan berdasarkan nilai media audio visual di $\mathrm{RA} \mathrm{Hj}$. Fauziah Binjai didapatkan hasil yaitu $\mathrm{P}=72,93 \%$. Berdasarkan nilai tersebut dapat dikatakan bahwa media audio visual siswa di RA Hj. Fauziah Binjai termasuk baik. Nilai persentase moral anak pada kelompok B siswa di $\mathrm{RA} \mathrm{Hj}$. Fauziah Binjai adalah sebesar 80,38\%. Berdasarkan nilai tersebut dapat dikatakan bahwa moral anak siswa di RA Hj. Fauziah Binjai termasuk sangat baik.

Berdasarkan uji statistik $\mathrm{t}$ yaitu $\mathrm{t}$ hitung $=\mathrm{r} \sqrt{ }(\mathrm{n}-1)$ didapatkan hasil 3,18. Jadi, dapat disimpulkan bahwa terdapat pengaruh yang signifikan antara media audio visual dengan moral anak pada kelompok $\mathrm{B}$ di $\mathrm{RA} \mathrm{Hj}$. Fauziah Binjai.

\section{SIMPULAN}

Berdasarkan hasil penelitian yang diperoleh, maka dapat diambil kesimpulan dari penelitian ini sebagai berikut:

Penelitian dengan media audio visual siswa di RA $\mathrm{Hj}$. Fauziah Binjai dapat dikatakan baik. Hal ini dapat dibuktikan dengan nilai yang diperoleh yaitu $\mathrm{P}=$ 72,93\%. Penelitian untuk moral anak pada kelompok B di RA Hj. Fauziah Binjai dapat dikatakan sangat baik. Hal ini dapat dibuktikan dengan nilai yang diperoleh yaitu $\mathrm{P}=80,38 \%$. Terdapat pengaruh yang signifikan antara media audio visual moral anak pada kelompok B di $\mathrm{RA} \mathrm{Hj}$. Fauziah Binjai yang dibuktikan dengan nilai koefisien korelasi (r) yang menunjukkan tingkat korelasi antara variabel $\mathrm{X}$ (media audio visual) dan variabel $\mathrm{Y}$ (moral anak pada kelompok B) sebesar $r=0,68$ dengan tingkat korelasi tinggi. Berdasarkan uji statistik $\mathrm{t}$ yaitu $\mathrm{t}$ hitung $=\mathrm{r} \sqrt{\mathrm{n}-1}$ didapatkan hasil 3,18. Jadi, dapat disimpulkan bahwa 
terdapat pengaruh yang signifikan antara media audio visual terhadap moral anak pada kelompok B di RA Hj. Fauziah Binjai.

\section{DAFTAR PUSTAKA}

Aisyah, Siti. 2012. Perkembangan Dan Konsep Dasar Pengembangan Anak Usia Dini. Jakarta: Universitas Terbuka.

Ananda, Rizki. 2017. "Implementasi NilaiNilai Moral Dan Agama Pada Anak Usia Dini." Jurnal Obsesi: Jurnal Pendidikan Anak Usia Dini 1 (1): 19. https://doi.org/10.31004/obsesi.v1i1.28.

Arikunto, S. 2015. Prosedur Penelitian Suatu Pendekatan Praktek. Jakarta: Rineka Cipta.

Djamarah, Syaiful Bahridan, and Aswan Zain. 2010. Strategi Belajar Mengajar. Jakarta : Rineka Cipta.

Ernayanti, Luh Wiwin, Ketut Pudjawan, and Luh Putu Putrini Mahadewi. 2017. "Pengaruh Metode Bercerita Bermediakan Audio Visual Pembelajaran Terhadap Kemampuan Menyimak Anak Gugus III Kecamatan Buleleng." E-Journal Pendidikan Anak Usia Dini Universitas Pendidikan Ganesha Jurusan Pendidikan Guru Pendidikan Anak Usia Dini 5 (3): 32535.

Fithri, Radhiyatul, and Rensia Pradipta. 2017. "Penerapan Media Audio Visual Untuk Meningkatkan Perekembangan Moral Anak Usia 5-6 Tahun Di PAUD Cemara Indah Kota Pekan Baru." PAUD Lectura: Jurnal Pendidikan Anak Usia Dini 1 (1): 58-71.

Fitria, Ayu. 2014. "Penggunaan Media Audio Visual Dalam Menunjang Pembelajaran Anak Usia Dini." Cakrawala Dini 05 (02): 1-8.

Jalil, Nurlina, and St Hawang. 2018. "Penerapan Media Audio Visual (Laptop) Dalam Meningkatkan Kemampuan Kognitif Anak Usia Dini." Jurnal Al-Athfal Jurnal Pembelajaran
Dan Pendidikan Anak Usia Dini 1 (1): 30-37.

Khaironi, Mulianah. 2017. "Pendidikan Moral Pada Anak Usia Dini." Jurnal Golden Age 1 (01): 1. https://doi.org/10.29408/goldenage.v1i 01.479 .

Maharani, Laila. 2014. "Perkembangan Moral Pada Anak." KONSELI: Jurnal Bimbingan Dan Konseling (E-Journal) 01 (2): 93-98. http://ejournal.radenintan.ac.id/index.p hp/konseli/article/download/1483/1219.

Oktaviani, Dina, and Kamtini. 2017. "Pengaruh Penggunaan Media Audiovisual Terhadap Kemampuan Membaca Permulaan Anak Usia 5-6 Tahun Di TK Salsa T.A 2016/2017." Bunga Rampai Usia Emas 3 (1): 2639.

Primayana, Kadek Hengki, Putu Yulia Angga Dewi, and Gede Dharman Gunawan. 2020. "Pengaruh Project Based Outdoor Learning Activity Menggunakan Media Audiovisual Terhadap Perilaku Belajar Anak Di PAUD." Pratama Widya: Jurnal Pendidikan Anak Usia Dini 5 (2): 13546.

Qadafi, Muammar. 2019. "Menumbuhkan Kesadaran Orang Tua Dalam Menanamkan Nilai Moral Anak Usia Dini Melalui Parenting Education." Pratama Widya: Jurnal Pendidikan Anak Usia Dini 4 (1): 57-65.

Siwiyanti, Leonita. 2016. "Pengembangan Moral Anak Usia Dini Dalam Membentuk Etika Wirausaha." Indira Lmiah Pendidikan PraSekolah Dan Sekolah Awal 1 (1): 22-31. file:///C:/Users/DELL/Downloads/PEN GEMBANGAN_MORAL_ANAK_US IA_DINI_DALAM_MEMBENTUK_. pdf.

Suparya, I Ketut. 2020. "Pengaruh Metode Bercerita Berbantuan Media Audio 
Visual Terhadap Perkembangan Bahasa Anak Usia Dini." Pratama Widya: Jurnal Pendidikan Anak Usia Dini 5 (2): 191-201.

Veryawan, Juliati, and Rapita Aprilia. 2020. "Kegiatan Menggambar Bebas Menggunakan Crayon Dalam Upaya Meningkatkan Kreativitas Anak Usia Dini." As Sibyan Jurnal Pendidikan Anak Usia Dini 4 (1): 129-38. https://doi.org/http://dx.doi.org/10.3267 8/as-sibyan.v5i2.3624. 